Members. Benin, Burkina Faso, Côte d'Ivoire, Guinea-Bissau, Mali, Niger, Senegal, Togo.

Official language: French.

Headquarters: Avenue Abdoulaye Fadiga, Dakar, Senegal.

Website: http://www.bceao.int

Governor: Tiémoko Meyliet Koné (Côte d'Ivoire).

Publications. Rapport annuel (annual); Annuaire des Banques (annual); Bilan des Banques U.M.O.A. (annual); Notes d'information et statistiques (monthly bulletin).

\section{Common Market for Eastern and Southern Africa (COMESA)}

COMESA is an African economic grouping of 20 member states who are committed to the creation of a Common Market for Eastern and Southern Africa. It was established in 1994 as a building block for the African Economic Community and replaced the Preferential Trade Area for Eastern and Southern Africa, which had been in existence since 1981.

Members. Burundi, Comoros, Democratic Republic of the Congo, Djibouti, Egypt, Eritrea, Ethiopia, Kenya, Libya, Madagascar, Malawii, Mauritius, Rwanda, Seychelles, South Sudan, Sudan, Swaziland, Uganda, Zambia and Zimbabwe.

Objectives. To facilitate the removal of the structural and institutional weaknesses of member states so that they are able to attain collective and sustainable development.

Activities. COMESA's Free Trade Area (FTA) was launched on 31 Oct. 2000 at a Summit of Heads of States and Government in Lusaka, Zambia. The FTA participating states have zero tariff on goods and services produced in these countries.

In addition to creating the policy environment for freeing trade, COMESA has also created specialized institutions like the Eastern and Southern African Trade and Development Bank (PTA Bank), the PTA Reinsurance Company (ZEP-RE), the Clearing House and the COMESA Court of Justice, to provide the required financial infrastructure and service support. COMESA has also promoted a political risk guarantee scheme, the Africa Trade Insurance Agency (ATI), a Leather and Leather Products Institute (LLPI), as well as a cross-border insurance scheme, the COMESA Yellow Card.

Official languages: English, French, Portuguese.

Headquarters: COMESA Secretariat, COMESA Centre, Ben

Bella Road, PO Box 30051, 10101 Lusaka, Zambia.

Website: http://www.comesa.int

Secretary General: Sindiso Ngwenya (Zimbabwe).

\section{East African Community (EAC)}

The East African Community (EAC) was formally established on 30 Nov. 1999 with the signing in Arusha, Tanzania of the Treaty for the Establishment of the East African Community. The Treaty envisaged the establishment of a Customs Union, as the entry point of the Community, a Common Market, subsequently a Monetary Union and ultimately a Political Federation of the East African States. In Nov. 2003 the EAC partner states signed a Protocol on the Establishment of the East African Customs Union, which came into force on 1 Jan. 2005. The Common Market came into force on 1 July 2010.
Members. Burundi, Kenya, Rwanda, Tanzania, Uganda.

Headquarters: Arusha International Conference Centre, 5th Floor, Kilimanjaro Wing, PO Box 1096, Arusha, Tanzania.

Website: http://www.eac.int

Secretary General: Dr Richard Sezibera (Rwanda).

\section{East African Development Bank (EADB)}

Established originally under the Treaty for East African Cooperation in 1967 with Kenya, Tanzania and Uganda as signatories, a new Charter for the Bank (with the same signatories) came into force in 1980. Under the original Treaty the Bank was confined to the provision of financial and technical assistance for the promotion of industrial development in member states but with the new Charter its remit was broadened to include involvement in agriculture, forestry, tourism, transport and the development of infrastructure, with preference for projects which promote regional co-operation.

Official language: English.

Headquarters: 4 Nile Avenue, PO Box 7128, Kampala, Uganda.

Website: http://www.eadb.org

Chair of the Governing Council: Syda Bbumba (Uganda).

\section{Economic Community of Central African States (CEEAC)}

The Economic Community of Central African States (Communauté Economique des Etats de l'Afrique Centrale) was established in 1983 to promote regional economic co-operation and to establish a Central African Common Market. There are plans for both a common market and a single currency.

Members. Angola, Burundi, Cameroon, Central African Republic, Chad, Democratic Republic of the Congo, Republic of the Congo, Equatorial Guinea, Gabon, São Tomé e Príncipe.

Headquarters: BP 2112, Libreville, Gabon.

Website: http://www.ceeac-eccas.org

President: Lieut.-Gen. Idriss Déby (Chad)

Secretary General: Louis Sylvain-Goma (Republic of the Congo).

\section{Economic Community of West African States (ECOWAS)}

Founded in 1975 as a regional common market, ECOWAS later also became a political forum involved in the promotion of a democratic environment and the pursuit of fundamental human rights. In July 1993 it revised its treaty to assume responsibility for the regulation of regional armed conflicts, acknowledging the inextricable link between development and peace and security. Thus it now has a new role in conflict management and prevention through its Mediation and Security Council, which monitors the moratorium on the export, import and manufacture of light weapons and ammunition. However, it still retains a military arm, the Economic Community of West African States Monitoring Group (generally known as ECOMOG). It is also involved in the war against drug abuse and illicit drug 